\title{
An Overview about the chemical composition and Biological Activity of Medicinal species found in the Brazilian Amazon
}

\author{
Fernanda Brum Pires ${ }^{1}$, Carolina Bolssoni Dolwitsch ${ }^{1}$, Valéria Dal Prá ${ }^{1}$, Débora Luana Monego ${ }^{2}$, Viviane Maria \\ Schneider ${ }^{2}$, Roberta Fabrício Loose ${ }^{2}$, Marcella Emília Petra Schmidt ${ }^{2}$, Lucas P. Bressan ${ }^{2}$, Marcio Antônio Mazutti ${ }^{3}$, \\ Marcelo Barcellos da Rosa ${ }^{1,2 *}$ \\ ${ }^{1}$ Post-Graduate Program in Pharmaceutical Sciences, Federal University of Santa Maria, Camobi Campus, Santa Maria, RS, 97105-900, Brazil. \\ ${ }^{2}$ Post-Graduate Program in Chemistry, Federal University of Santa Maria, Camobi Campus, Santa Maria, RS, 97105-900, Brazil. \\ ${ }^{3}$ Department of Chemical Engineering, Federal University of Santa Maria, Camobi Campus, Santa Maria, RS, 97105-900, Brazil.
}

\begin{tabular}{|c|c|}
\hline ARTICLE INFO & ABSTRACT \\
\hline Article history: & \multirow{9}{*}{$\begin{array}{l}\text { This paper presents an overview on the chemical composition and biological activity of plants found in the } \\
\text { Brazilian Amazon - Bauhinia variegata, Cecropia obtusa, Cecropia palmata, Connarus perrottetti var. } \\
\text { angustifolius, Chrysobalanus icaco and Mansoa alliacea. The lack of information regarding these species, along } \\
\text { with their importance given their pharmacological and nutritional use in Latin American folk medicine, justifies } \\
\text { the demand for this study. However, various interesting and important actions, as antioxidant, antibacterial, } \\
\text { cytotoxic, hypoglycemic, antifungal, antiangiogenic, antitumor, anti-inflammatory, antiulcer, and } \\
\text { chemopreventive have been modestly reported so far. In other words, these species can play a very important } \\
\text { role in terms of biological and chemical activity, but their pharmacology is still poorly investigated. } \\
\text { Accordingly, the discovery of molecules that could play a role against the major diseases of modern society } \\
\text { could be achieved by paving more attention to plants used daily in some regions of our country. }\end{array}$} \\
\hline Received on: 20/05/2016 & \\
\hline Revised on: 14/09/2016 & \\
\hline Accepted on: 11/11/2016 & \\
\hline Available online: $28 / 12 / 2016$ & \\
\hline & \\
\hline Biological activity, chemical & \\
\hline composition, Brazilian & \\
\hline Amazon, folk medicine. & \\
\hline
\end{tabular}

\section{INTRODUCTION}

The growing use of herbal medicine in recent decades, associated with the intense demand for biotech products, has attracted strong interest in pharmaceutical, cosmetic and food industries. About $30 \%$ of drugs available in the world market are currently derived from natural sources. This biological diversity translates into structural diversity, enabling the discovery of new classes of compounds and bioactive substances with therapeutic potential (Paracampo, 2011). The search for new medicinal molecules plays a paramount role on the global biotechnology industry development (Benini et al., 2010). In Brazil, many factors contribute to this scenario, such as the diversity of plants considered therapeutic and the reduced cost associated with their

* Corresponding Author

Email: marcelobdarosa@gmail.com acquisition. Furthermore, there is an incentive for the use of herbal products by the Unified Health System (SUS) of this country. The Amazon rainforest is house to approximately $50 \%$ of the global biodiversity, and $70 \%$ of its area is located in Brazilian territory. Consequently, Brazil is the country with the greatest potential for plant research (Port's et al., 2013). Recent data show that the Brazilian Amazon region has at least 45.000 different species of plants and many of them are rich in active ingredients (Rodrigues et al., 2010). However, the genetic resources of this vast biodiversity are still poorly explored, what is very surprising, given that they represent excellent sources of bioactive compounds, such as alkaloids, triterpenes and flavonoids that are able to protect the organism against damage caused by oxidative stress induced by free radicals (Neri-Numa et al., 2013). More than 50.000 species of plants naturally occurring in Brazilian Amazon have already been cataloged, representing nearly $20 \%$ of the world's total (Lopes and Link, 2011). 
In this sense, various genera have been identified in this ecosystem, from which stand out: Bauhinia, Cecropia, Connarus, Chrysobalanus and Mansoa, which are extensively reported in the literature by their pharmacological activity and nutritional properties, mostly recognized in the folk medicine.

The Bauhinia variegata is a leafy canopy of the legume family (Caesalpinioidae). Besides having white flowers and podfruits, its leaves are similar to a "paw-of-cow" or "ox-nail", which gave rise to the popular name of the genus. This species is mainly found in tropical regions of the world and is widely used as a remedy in folk medicine (Bianco and Santos, 2003; Pizzolatti et al., 2003).

The species Cecropia obtusa and Cecropia palmata belong to the family Moraceae (Sposito and Santos, 2001; Luengas-Caicedo, 2005) are popularly known as embaúva, imbaúba, imbaúva, umbaúba, umbaúva, ambaúba, embaíba, imbaíba, and toré. They are also recognized as the tree-of-laziness, since their leaves and fruits are commonly consumed by sloths. The species of the genus Cecropia can reach a height of fifty feet and are considered pioneer in the Atlantic Forest (Homma, 2003).

Connarus perrotteti var. angustifolius is believed to originate in America, being found mainly in North and CenterWest Brazil, where it is popularly called marassacaca or muraçacaca, pajurana or pajujurana, and raparigeira (Forero and Kamino, 2010). According to the regional population of Pará, this plant presents many healing effects, which may be obtained through various forms of extraction, such as maceration, tea or syrup. The most used part of this species are the barks, where the highest concentration of active compounds is found (CoelhoFerreira, 2009).

Chrysobalanus icaco L., popularly known as icaco, agirú, ajiru, and abajeru, belongs to the Chrysobalanaceae family, which consists of 17 genera and 450 species. It consists of a medium-sized shrub with oval leaves, native to coastal areas of southern Florida, Bahamas and Caribbean. It is also found in Africa, and South and Central America, including Mexico, Ecuador and northern Brazil (Fernandes et al., 2003). Besides possessing medicinal activity, its fruits are edible and are commercialized in some countries, either as a candy or canned (Fernandes et al., 2003; Ugent and Ochoa, 2006).

The Mansoa alliacea, in turn, is popularly known as garlic vine, because of the strong garlic odor exhaled when its leaves, stems, flowers and fruits are macerated. This similarity results on this plant being easily counterfeited, what is a very serious issue to the market of herbal medicinal products. Mansoa alliacea belongs to the Bignoniaceae family, which includes eleven other species, and is mainly found in the forests of Brazil, Argentina, and southeastern Mexico. This species is usually cultivated away from water bodies, in shaded areas and with low vegetation density, since it is not able to grow in flooded areas or open fields (Zoghbi et al., 2009).

The medicinal actions of plants are attributed, at least partially, to the presence of secondary metabolites in their composition (Parekh et al., 2006). Therefore, we aimed to describe the phytocompounds already identified in species, as well as their predicted biological activities, relating one another.

\section{POPULAR USE, CHEMICAL COMPOSITION AND BIOLOGICAL ACTIVITY}

Works regarding the chemical composition of the species reviewed in this study are summarized in Table 1 while biological activities reported in the literature concerning the species reported in this study are summed up in Table 2.

The majority of the studies found in literature concerning these plants are related to Bauhinia variegate (Table 2) while other genera and species reported in this survey are far less explored.

Bauhinia variegata is popularly used by its hypoglycemic, diuretic, anti-inflammatory (Duarte et al., 2007), antibacterial, healing and expectorant activity (Mishra et al., 2013; Bansal et al., 2015). Several studies demonstrating the biological activity of Bauhinia variegata are found in the literature (Table 2). Amongst them, we can highlight the tests carried out by Mishra et al., (2013) showing the potential antibacterial, antioxidant and antitumoral roles of the leaf extracts of this plant. The analysis conducted by the authors acknowledged the presence of various classes of phytocompounds, such as terpenes, phenols, flavonoids, tannins, saponins, anthraquinones and alkaloids. The antimicrobial activity attributed to this plant might be related to the presence of alkaloids, tannins and flavonoids in its composition. The latter compounds also contribute to the antioxidant and anticancer capability of this plant extracts, alone or in combination with anthraquinones and saponins.

Many species of the Bauhinia genus are widely used in folk medicine as hypoglycemic agents (Silva and Cechinel Filho, 2002; Saravanamuttu and Sudarsanam, 2012). This medicinal action was previously confirmed, as the Bauhinia variegata leaf extracts lowered blood glucose in rats (Thiruvenkatasubramaniam and Jayakar, 2010). This effect can be attributed to the presence of flavonoids in its composition (Saravanamuttu and Sudarsanam, 2012). Accordingly, kampferol, quercetin, and rutin, were identified by previous studies presented (Rao, 2008; Silveira et al., 2015) (Table 1).

There is a lack of studies investigating the species Bauhinia variegata var. alboflava. However, the literature reports presence of caffeic acid, rutin, and quercitrin in its composition (Silveira et al., 2015).

There are numerous species of the Connarus genus with promising pharmacological activities, and a wide range of phytocompounds have been identified in these plants. However, only recently the Connarus perrottetti var. angustifolius species became a target of investigation (Paracampo, 2011). Surprisingly, this plant is widely used by local population with medicinal purposes (Roman and Santos, 2006; Coelho-Ferreira, 2009). This species was analyzed by Coelho-Ferreira (2009), who evaluated its action on the treatment of genitourinary infections in women, cystic ovaries, vaginal discharge, gastric diseases, headaches, flu, cough, and congestion. 
Table 1: Major compounds isolated from species of interest found in the Brazilian Amazon and the respective characterization methods employed.

\begin{tabular}{|c|c|c|}
\hline Species & Isolated major compounds & Method of characterization \\
\hline \multirow{8}{*}{ Bahunia variegata } & Chlorogenic & HPLC-PAD ${ }^{\mathrm{a}}$ (Silveira et al., 2015) \\
\hline & acid, ferullic acid, rutin, quercetin & $\mathrm{RMN}^{\mathrm{b}} 1 \mathrm{H}$ e $13 \mathrm{C} ; \mathrm{ESI}^{-M S^{c}}$ (Rao et al., 2008) \\
\hline & Flavonoids (canferol), terpenes & Phytochemical analysis \\
\hline & Phenolic compounds, tannins, & (Ahmed et al., 2012) \\
\hline & proanthocyanidins & Spectroscopic analysis (Saha et al., 2011) \\
\hline & Terpenes: (lupeol, $\alpha$-amyrin caprylate), fatty & Spectrophotometry (Martinez et al., 2011) \\
\hline & acids & \\
\hline & Alkaloids & \\
\hline Bauhinia var alboflava & Cafeic acid, rutin, quercitrin & HPLC-PAD $^{\text {a }}$ (Silveira et al., 2015) \\
\hline \multirow[t]{2}{*}{ Cecropia obtusa } & $\begin{array}{l}\text { Caffeic acid, } p \text { - coumaric acid, resveratrol } \\
\text { Chlorogenic }\end{array}$ & HPLC-PAD $^{\mathrm{a}}$ (Silveira et al., 2015) \\
\hline & acid, caffeic acid, resveratrol, rutin, $p$ - & HPLC-PAD $^{\mathrm{a}}$ (Silveira et al., 2015) \\
\hline Cecropia palmata & $\begin{array}{l}\text { coumaric acid, ferulic acid, catechin } \\
\text { Terpenes: ursolic acid, } \alpha \text {-amyrin, } \beta \text {-amyrin, } \\
\text { lupeol, pomolic acid, coumarin (scopoletin), } \\
\text { steroids }\end{array}$ & IR spectroscopy ${ }^{\mathrm{d}}, 1 \mathrm{H}$ and 13C NMR ${ }^{\mathrm{b}}$ (Pinheiro, 1999) \\
\hline \multirow{4}{*}{ Connarus perrottetti var. angustifolius } & Saponin, coumarin, flavonoids, tannins, & Phytochemical analysis (Oliveira, 2013) \\
\hline & glycoside & HPLC-PAD ${ }^{\mathrm{a}}$ (Silveira et al., 2015 \\
\hline & cardiotonics & Capillary Electrophoresis-CZE with UV detection ${ }^{\mathrm{e}}$ \\
\hline & Gallic acid, caffeic acid, Catechin, rutin & (Müller et al., 2016) \\
\hline \multirow{7}{*}{ Chrysobalanus icaco } & Gallic acid, quercetin, miricitin & HPLC-DAD $^{\mathrm{f}}$ (Port's et al., 2013) \\
\hline & betulinic, oleanolic, pomolic acids & GC/MS ${ }^{\mathrm{g}}, 1 \mathrm{H}$ and $13 \mathrm{C} \mathrm{NMR}^{\mathrm{b}}$ (Fernandes et al., 2003) \\
\hline & myricetin derivatives & HPLC-DAD ${ }^{\text {f }}$ and HPLC/MS ${ }^{\text {h }}$ (Barbosa et al., 2006) \\
\hline & Anthocyanins & Chromatography paper and Spectrophotometry UV/VIS ${ }^{\mathrm{i}}$ \\
\hline & Pomolic acid, & (Vargas-Simón et al., 2002) \\
\hline & 7-O-methyl kaempferol & GC/MS ${ }^{\mathrm{g}}($ Vargas et al., 2010) \\
\hline & & $\begin{array}{l}\text { Column chromatography, HPLC (reverse phase) GC/MS } \\
1 \mathrm{H} \text { and } 13 \mathrm{C} \mathrm{NMR}^{\mathrm{b}} \text { (Castilho and Kaplan, 2011) }\end{array}$ \\
\hline \multirow{3}{*}{ Mansoa alliacea } & $\begin{array}{l}\text { Tannin, flavonoids, terpenes, alkaloid, cumarin, } \\
\text { saponin }\end{array}$ & $\begin{array}{l}\text { Phytochemical analysis (Patel et al., 2013; Ribeiro, 2008; } \\
\text { Ribeiro et al., 2009; Oliveira, 2013) }\end{array}$ \\
\hline & $p$-coumaric acid, ferulic acid, resveratrol & HPLC-PAD ${ }^{\mathrm{a}}$ (Silveira et al., 2015) \\
\hline & Sulfur compounds & GC/MS ${ }^{g}$ (Zoghbi et al., 2002; Zoghbi et al., 2009) \\
\hline
\end{tabular}
chromatography.

Table 2: Biological activity from species of interest in the Brazilian Amazon.

\begin{tabular}{|c|c|c|}
\hline Species & Popular name & Biological activity \\
\hline Bauhinia variegata & $\begin{array}{l}\text { "Paw-of-cow" } \\
\text { "Nail-of-cow" } \\
\text { "Hull-of-cow" }\end{array}$ & $\begin{array}{l}\text { *Antitumor (Rajkapoor et al., 2003; Mishra et al., 2013) } \\
\text { *Antiulcer (Rajkapoor et al., 2003) } \\
\text { *Chemopreventive and cytotoxic (Rajkapoor et al., 2006) } \\
\text { *Anti-inflammatory (Rao et al., 2008) } \\
\text { *Hypoglycemic (Thiruvenkatasubramaniam and Jayakar, 2010) } \\
\text { *Antioxidant (Ahmed } \text { et al., 2012; Mishra et a., 2013) } \\
\text { *Cytotoxic (Martinez et al., 2011) } \\
\text { *Hepatoprotective (Gupta } \text { et al., 2015) } \\
\text { * Antibacterial (Parekh } \text { et al., 2006; Mishra et al., 2013) }\end{array}$ \\
\hline Cecropia obtuse and C. palmata & "White Embaúba" and "Red Embaúba" & *Antioxidant (Silva et al., 2007) \\
\hline Connarus perrottetii var. angustifolius & "Barbatimão" & $\begin{array}{l}\text { *Cytotoxic (Suffredini et al., 2007) } \\
\text { *Inhibition of histamine release - Antiallergic (Oliveira, 2013) }\end{array}$ \\
\hline Chrysobalanus icaco & $\begin{array}{l}\text { "Abajeru" } \\
\text { "Agiru" } \\
\text { "Ajiru" }\end{array}$ & $\begin{array}{l}\text { *Antiangiogenic (Paulo et al., 2000) } \\
\text { *Antitumor (Fernandes et al., 2003) } \\
\text { *Antibacterial (Castilho and Kaplan, 2011) } \\
\text { *Antioxidant (Port's et al., 2013) }\end{array}$ \\
\hline Mansoa alliacea & "Garlic vine or D'garlic vine" & $\begin{array}{l}\text { *Antifungal (Freixa et al., 1998) } \\
\text { *Antiviral (Khurana and Bhargava, 1970; Zoghbi et al., 2009) } \\
\text { *Antibacterial (Araújo, 2010) } \\
\text { *Suppression of tumor growth (Towne et al., 2015) } \\
\text { *Inhibition of histamine release- Antiallergic (Oliveira, 2013) } \\
\text { *Anti-inflammatory (Dunstan et al., 1997; Zoghbi et al., 2009) } \\
\text { *Antioxidant (Desmachelier et al., 1997; Zoghbi et al., 2009) }\end{array}$ \\
\hline
\end{tabular}


Moreover, Oliveira (2013) demonstrated the anti-allergic property of Connarus perrottetti var. angustifolius, due the inhibition of histamine production by its leaf and bark extracts. This activity, which is more effective in bark extracts, is attributed to the presence of flavonoids, catechins, and tannins, which were identified by phytochemical analysis. Another study detected gallic acid, catechin, caffeic acid, and rutin employing highperformance liquid chromatography and capillary electrophoresis (Silveira et al., 2015; Muller et al., 2016).

Species of Cecropia genus are commonly used to treat respiratory diseases, such as cough and asthma, as an expectorant and to treat hypertension. The species show anti-inflammatory, antimicrobial and diuretic activity (Arend et al., 2006; Costa et al., 2011). One can evidence a shortage of biological studies regarding the chemical composition of Cecropia palmata (phenolic acids, flavonoids, resveratrol) and Cecropia obtusa (phenolic acids and resveratrol) (Silveira et al., 2015) (Table 1). Silva et al., (2007) discussed the antioxidant potential of C. palmata and suggested that more studies are needed. Pinheiro (1999) isolated and identified ursolic acid terpenes, $\alpha$-amyrin, $\beta$-amyrin, lupeol, pomolic acid, and phytol in samples of Cecropia palmata.

In the same work that evaluated Connarus angustifolius, Oliveira (2013) examined Mansoa alliacea leaf extracts, which also inhibited the release of histamine, but only in high concentrations. Therefore, the latter species showed a smaller potential antiallergic activity than the former. The presence of coumarins in Mansoa alliacea composition, along with its phenolic content, is associated with the medicinal actions attributed to this plant, as reported in the literature (Gonsior et al., 1979; Choi and Yan, 2009; Santos, 2012). Tudela-Talavera (2016) and Zoghbi, et al., (2009) cited several popular uses of Mansoa alliacea for the treatment of cough, nausea, fever, flu, diarrhea, rheumatic pains, among others. Zoghbi et al., (2009) state that the essential oil of this species is composed by various sulfur compounds, which showed antinflammatory and antimicrobial activity and may be responsible for the medicinal actions of the plant. Other classes of secondary metabolites and specific compounds were identified in the species and are referenced in Table 1. Antifungal (Freixa et al., 1998) and antibacterial activity (Araujo, 2010) are also reported. However, the lack of studies showing the compounds responsible for such actions emphasizes the need to deeply explore the potential of this plant.

Chrysobalanus icaco is popularly used on the control the blood glucose levels (Presta et al., 2007; Coelho-Ferreira, 2009).The infusions of fruits, leaves, barks or roots are employed in the treatment of chronic diarrhea, bleeding and leukorrhea. Additionally, leaves of this plant are used as diuretic and hypoglycemic (Paulo de et al., 2000). Port's et al., (2013) found relevant phenolic compounds in Chrysobalanus icaco, which are directly associated with the antioxidant activity of the extract obtained by infusion of leaves of this plant (Table 1). Furthermore, Castilho and Kaplan (2011) reported the antibacterial activity of Chrysobalanus icaco extracts and of 7-O-methylkaempferol, isolated from this species, against microorganisms such as Staphylococcus aureus and Streptococcus pyogenes.

The antitumor activity was observed for all species, except the ones of Cecropia genus (Table 2). Rajkapoor et al., (2003) verified the antitumor action of Bauhinia variegata against Dalton's ascitic lymphoma, since the extract was able to increase the average survival time of the mice assessed. Also, fractions of $B$. variegata leaves showed pronounced cytotoxic effect against different tumor cell lines such asprostate, lung, ovary, breast and leukemic (Mishra et al., 2013).

Triterpenes as betulinic, pomolic and oleanolic acids were isolated from leaves of Chrysobalanus icaco, and were able to inhibit the growth and apoptosis of leukemic tumor cells (Fernandes et al., 2003). Suffredini et al., (2007) assessed the cytotoxicity of Connarus perrottetti leaves in cancer cells and also observed that they were able to inhibit their growth. Similarly, Towne et al., (2015) observed this effect for Mansoa alliacea leaves, highlighting the antitumor potentiality of such species.

\section{CONCLUSION}

This work has analyzed and compiled information regarding the species Bauhinia variegata, Cecropia obtusa, Cecropia palmata, Connarus perrottetii var. angustifolius, Chrysobalanus icaco, and Mansoa alliacea. These common species of the Brazilian Amazon region, widely used in folk medicine, show antioxidant, antibacterial, cytotoxic, hypoglycemic, antifungal, antiangiogenic, antitumor, antiinflammatory and antiallergic activity. However, many studies regarding the biological activity of such plants pay little attention to the constituents responsible for their medical actions. Therefore, more examination is required regarding both biological and chemical activity. Such investigations could lead to the discovery of new compounds and confirm these pharmacological effects. Based on the outcomes of these studies, the evaluated plants may become potential herbal products.

\section{Financial support and sponsorship: Nil.}

Conflict of Interests: There are no conflicts of interest.

\section{REFERENCES}

Ahmed AS, Elgorashi EE, Moodley N, McGaw LJ, Naidoo V, Eloff JN. The antimicrobial, antioxidative, anti-inflammatory activity and cytotoxicity of different fractions of four South African Bauhinia species used traditionally to treat diarrhea. J Ethnopharmacol, 2012; 143: 826839.

Araújo NRR. In vitro antimicrobial activity of plant extracts on microorganisms related to injury of oral mucositis. Dissertação, Universidade Federal do Pará, 2010.

Arend DP. Desenvolvimento de sistema microestruturado contendo extrato padronizado de Cecropia glaziovii Sneth (Embaúba). Dissertação, Universidade Federal de Santa Catarina, 2010.

Bansal V, Malviya R, Deeksha, Malaviya T, Sharma PK. Phytochemical, pharmacological profile and commercial utility of 
tropically distributed plant Bauhinia variegata. Global J Pharmacol, 2014; 8(2): 196-205.

Barbosa WLR, Peres A, Gallori S, Vincieri FF. Determination of myricetin derivatives in Chrysobalanus icaco L. (Chrysobalanaceae). Braz J Phamacog, 2006; 16(3): 333-337.

Benini EB, Sartori MAB, Busch GC, Rempel C, Schultz G, Strohschoen AAG. Valorização da flora nativa quanto ao potencial fitoterápico. Revista destaques acadêmicos CCBS/UNIVATES, 2010; 2(3): 11-17.

Bianco EM, Santos CAM. Substâncias isoladas das folhas de Bauhinia microstachya (Raddi) Macbr (Caesalpiniaceae). Braz J Farmacog, 2003; 13(2): 93-99.

Castilho RO, Kaplan MAC. Phytochemical study and antimicrobial activity of Chrysobalanus icaco. Chem Nat Compd, 2011; 47: 436-437.

Coelho-Ferreira M. Medicinal knowledge and plant utilization in an Amazonian coastal community of Maruda, Pará State (Brazil). J Ethopharmacol, 2009; 126: 159-175.

Costa GM, Ortmann CF, Schenkel EP, Reginatto FH. An HPLC-DAD Method to Quantification of Main Phenolic Compounds from Leaves of Cecropia Species. J Braz Chem Soc, 2011; 22(6): 1096-1102.

Choi YH, Yan GH. Anti-allergic effects of scoparone on mast cell-mediated allergy model. Phytomedicine, 2009; 16(12): 1089-1094.

Desmachelier C, Repetto M, Coussio J, Llesuy S, Ciccia G. Total reactive antioxidant potential (TRAP) and total antioxidant reactivity (TAR) of medicinal plants used in Southwest Amazonia (Bolivia and Peru). Int J Pharmacog, 2007; 35: 1-9.

Duarte MR, Silva AG, Costa RE, Faria LT. Bauhinia variegata: Diagnose Morfoanatômica e Análise Comparativa entre Exemplares de Regiões Climáticas Distintas. Lat Am J Pharm, 2007; 26(6): 837-845.

Dunstan CA, Noreen Y, Serrano G, Cox PA, Perera P, Bohlin L. Evaluation of some Samoan and Peruvian medicinal plants by prostaglandin biosynthesis and rat ear oedema assays. J Ethnopharmacol, 1997; 57(1): 35-56.

Fernandes J, Castilho RO, Costa MR, Wagner-Souza K, Maria ACK, Cerli RG. Pentacyclic triterpenes from Chrysobalanaceae species: cytotoxicity on multidrug resistant and sensitive leukemia cell lines. Cancer Lett, 2003; 190: 165-169.

Forero E, Kamino, LHY. 2010. Connaraceae In: LISTA de Espécies da Flora do Brasil. Rio de Janeiro: Jardim Botânico do Rio de Janeiro, Disponível em: http://floradobrasil. jbrj.gov.br/2010/FB082007. Accessed in: May $14^{\text {th }}$.

Freixa B, Vila R, Vargas L, Lozano N, Adzet T, Cañigueral S. Screening for Antifungal Activity of Nineteen Latin American Plants. Phytother Res, 1998; 12: 27-43.

Gonsior E, Schultze-Werninghaus G, Wüthrich B. Protective antiallergic effects of a new coumarin compound (BM 15.100) in experimental asthma. International Journal of Clinical Pharmacology and Biopharmacy, 1979; 17(7): 283-289.

Gupta A, Shethb NR, Pandeya S, Yadavc JS, Joshi SV. Screening of flavonoids rich fractions of three Indian medicinal plants used for the management of liver diseases. Braz J Pharmacog, 2015; 25; 485-490.

Homma AK. 2003. História da Agricultura na Amazônia: das era pré-colombiana ao terceiro milênio. Embrapa Amazônia Oriental. Infoteca Embrapa: Belém, PA.

Khurana SMP, Bhargava KS 1970. Effect of plant extracts on the activity of three papaya viruses. J Gen Appl Microbiol 16: 225-230.

Lopes JMC, Link D. Implantação de um horto didático de plantas bioativas no município de Tupanciretã. Revista Eletrônica em Gestão, Educação e Tecnologia Ambiental REGET-CT/UFSM, 2011; 2: 225-250. Available in: http://periodicos.ufsm.br/reget/article/view/2781. Accessed in: May $12^{\text {th }}$

Luengas-Caicedo PE. Contribuição para a padronização de extratos de folhas de Cecropia glaziovii snethl.: estudos de variação sazonal e intra-específica de flavonóides e proantocianidinas, de metodologias de extração e de atividade vasorelaxante. Tese, Universidade Federal de Minas Gerais, 2005.
Martínez M, Ocampo D, Galvis J, Valencia A. Antibacterial activity and in vivo cytotoxicity of ethanol extracts from Bauhinia variegata L. (Fabaceae). Cuban Journal of Medicinal Plants, 2011; 16: 313-323.

Mishra A, Sharma AK, Kumar S, Saxena AK, Pandey AK. Antibacterial, Antioxidant, and Anticancer Activities. BioMed Res International, 2013; 2013: 10 pages.

Müller LS, Silveira GD, Dal Prá V, Lameira O, Viana C, de Carvalho LM. Investigation of phenolic antioxidants as chemical markers in extracts of Connarus perrottetii var. angustifolius Radlk by capillary zone electrophoresis. J Liq Chrom Relat Tech, 2016; 39(1): 13-20.

Neri-Numa IA, Carvalho-Silva LB, Morales JP, Malta LG, Muramoto MT, Ferreira JEM, De Carvalho JE, Ruiz ALTG, Maróstica Junior MR, Pastore GM. Evaluation of the antioxidant, antiproliferative and antimutagenic potential of araçá-boi fruit (Eugenia stipitata McVaugh -Myrtaceae) of the Brazilian Amazon Forest. Food Res Int, 2013; 50: 7076

Oliveira DMC. Triagem de cinco espécies de plantas medicinais usadas na Amazônia através da análise de secreção de histamina. Tese, Universidade Federal do Pará, 2013.

Paracampo NENP. 2011. Connarus perrottetii var. angustifolius Radlk. (Connaraceae): tradicionalmente utilizada como barbatimão no Pará. Embrapa Amazônia Oriental. Infoteca Embrapa: Belém, PA.

Parekh J, Karathia N, Chanda S. Evaluation of antibacterial activity and phytochemical analysis of Bauhinia variegata $L$. bark. African Journal of Biomedical Research, 2006; 9: 53-56.

Patel I, Sipai S, Rathod D, Shrimali G, Patel A, Rami E. Phytochemical studies on Mansoa alliacea (Lam.). International Journal of Advances in Pharmaceutical Research, 2013; 4(6): 1823-1828.

Paulo de AS, Balassiano TI, Silva HN, Castilho OR, Kaplan MAC, Cabral CM, Carvalho MGC. Chrysobalanus icaco L. Extract for antiangiogenic potential observation. Int J Mol Med, 2000; 5: 667-669.

Pinheiro GBV. Terpenoids de Cecropia palmata (Moraceae). Dissertação, Universidade Federal do Pará, Belém, 1999.

Pizzolatti MG, Cunha Jr A, Szpoganicz B, de Sousa E, BrazFilho R, Schripsema J. Flavonóides glicosilados das folhas e flores de Bauhinia forticata (Leguminosae). Química Nova, 2003; 26(4): 466-469.

Port's PSP, Chisté RC, Godoy HT, Prado MA. The phenolic compounds and the antioxidant potential of infusion of herbs from the Brazilian Amazonian region. Food Res Int, 2013; 53: 875-881.

Presta GA, Fonseca AS, Bernardo-Filho M. A Chrysobalanus icaco extract alters the plasmid topology and the effects of stannous chloride on the DNA of plasmids. Rev bras farmacogn, 2007; 17(3): 331335 .

Rajkapoor B, Jayakar B, Anandan R, Kavimani S. Anti-ulcer effect of Bauhinia variegata Linn in rats. J Nat Remedies, 2003; 3: 215 216.

Rajkapoor B, Jayakar B, Murugesh N, Sakthisekaran D. Chemoprevention and cytotoxic effect of Bauhinia variegata against $\mathrm{N}$ nitrosodiethylamine induced liver tumors and human cancer cell lines. Journal of Ethnopharmacol, 2006; 104: 407-409.

Rajkapoor B, Jayakar B, Murugesh N. Antitumour activity of Bauhinia variegata on Dalton's ascitic lymphoma. J Ethnopharmacol, 2003; 89: 107-109.

Rao YK, Fang SH, Tzeng YM. Antiinflammatory activities of flavonoids and a triterpene caffeate isolated from Bauhinia variegata. Phytother Res, 2008; 22: 957-962.

Ribeiro CM, Souza KG, Ribeiro TT, Vieira AR, Mendonça, LC, Barbosa WL, Vieira JMS. Avaliação da atividade antimicrobiana de plantas utilizadas na medicina popular da Amazônia. Infarma, 2009; 21: 45-49.

Ribeiro CM. Avaliação da atividade antimicrobiana de plantas utilizadas na medicina popular da Amazônia. Dissertação, Universidade Federal do Pará, 2008.

Rodrigues E, Duarte-Almeida JM, Pires JM. Perfil farmacológico e fitoquímico de plantas indicadas pelos caboclos do Parque Nacional do Jaú (AM) como potenciais analgésicas parte I. Braz J of Pharmacog, 2010; 20(6): 981-991. 
Roman ALC, dos Santos JUM. A importância das plantas medicinais para a comunidade pesqueira de Algodoal. Bol Mus Para Emílio Goeldi, sér Ciências Naturais, 2006; 1(1): 69-80.

Saha S, Subrahmanyam EVS, Kodangala C, Shastry SC. Isolation and characterization of triterpenoids and fatty acid ester of triterpenoid from leaves of Bauhinia variegata. Der Pharma Chem, 2012; 3:28-37.

Santos MS. Estudo da sinalização de mastócitos mediada por IgE: desenvolvimento de inibidores e efeito de níveis reduzidos de fosfatidilinositol 4,5-bifosfato 2012. Tese, Faculdade de Ciências Farmacêuticas de Ribeirão Preto, 2012.

Saravanamuttu S, Sudarsanam D. Antidiabetic plants and their active ingredients: a review. Int J Pharm Sci Res, 2012; Vol. 3(10): 36393650 .

Silva EM, Souza JNS, Rogez H, Larondelle Y. Antioxidant activities and polyphenolic contents of fifteen selected plant species from the Amazonian region. Food Chemistry, 2007; 101: 1012-1018.

Silva KL, Cechinel Filho V. Plantas do gênero bauhinia: composição química e potencial farmacológico. Quim Nova, 2002; 25(3): 449-454.

Silveira GD, Motta MJ, Muller LS, Lameira O, Athayde ML, Piana M, da Rosa MB, Viana C, de Carvalho LM. Determination of Phenolic Antioxidants in Amazonian Medicinal Plants by HPLC with Pulsed Amperometric Detection. J Liquid Chromatography Related Technologies, 2015; 38: 1259-1266.

Sposito TC, Santos FAM. Scaling of stem and crown in eight Cecropia (cecropiaceae) species of Brazil. Am J Bot, 2001; 88: 939-949.

Suffredini IB, Paciencia MLB, Varella AD, Younes RN. In vitro cytotoxic activity of Brazilian plant extracts against human lung, colon and CNS solid cancers and leukemia. Fitoterapia, 2007; 78: 223 226.

Thiruvenkatasubramaniam R, Jayakar B. Anti-hyperglycemic and anti-hyperlipidaemic activities of Bauhinia variegata L. on streptozotocin induced diabetic rats. Global J Pharmacol, 2010; 4: 83-86.

Towne CM, Dudt JF, Ray DB. Effect of Mansoa alliacea (Bignonaceae) leaf extract on embryonic and tumorigenic mouse cell lines. J Med Plants Res, 2015; 9(29): 799-805.
Tudela-Talavera P, La Torre-Cuadros M. Cultural importance and use of medicinal plants in the shipibo-conibo native community of Vencedor (Loreto) Peru. Ethno Res Applicat, 2016; 14: 533-548.

Ugent D, Ochoa CM. 2006. La etnobotánica del Perú: desde la Prehistoria al Presente. Lima: Imprenta Universidade Nacional Mayor San Marcos.

Vargas CE, Mendes MF, Azevedo DA, Pessoa FLP, Uller AC. Extraction of the essential oil of abajeru (Chrysobalanus icaco L.) using supercritical CO2. J Supercrit Fluids, 2010; 54:171-177.

Vargas-Simón G, Soto-Hernández RM, Rodríguez-González MT. Preliminar analysis of anthocyanins of the cocoplum fruit (Chrysobalanus icaco L.). Rev Fitotec Mex, 2002; 25(3): 261-264.

Zoghbi MGB, Andrade EHA, Maia JGS. Volatile constituents from Adenocalymma alliaceum Miers and Petiveria alliacea L., two medicinal herbs of the Amazon. Flavour Frag J, 2002; 17: 133-135.

Zoghbi MGB, Oliveira J, Skelding GM, Guilhon P. The genus Mansoa (Bignoniaceae): a source of organosulfur compounds. Braz J Pharmacog, 2009; 19: 795-804.

\section{How to cite this article:}

Pires FB, Dolwitsch CB, Prá VD, Mônego DL, Schneider VM, Loose RF, Schmidt MEP, Bressan LP, Mazutti MA, Rosa MB. An Overview about the chemical composition and Biological Activity of Medicinal species found in the Brazilian Amazon. J App Pharm Sci, 2016; 6 (12): 233-238. 